\title{
XVI. A voltameter for small currents
}

\section{R.A. Lehfeldt}

To cite this article: R.A. Lehfeldt (1902) XVI. A voltameter for small currents, Philosophical Magazine Series 6, 3:13, 158-159, DOI: 10.1080/14786440209462749

To link to this article: http://dx.doi.org/10.1080/14786440209462749

$$
\text { 曲 Published online: 09 Jun } 2010 .
$$

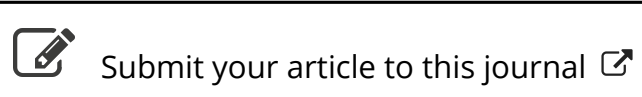

Џll Article views: 2

Q View related articles $\asymp$ 
could not obtain this substance, even after repeated attempts at purification, in the same condition of purity as the carbon dioxide. The observations showed this distinctly. The change of pressure with change of volume was for one sample from 23.61 to 23.97 atmos. at $0^{\circ} \mathrm{C}$., and for a second sample 18.40 to 18.57 at $-9^{\circ} .7 \mathrm{C}$. On being heated or cooled the substance took a considerable time to attain a constant pressure : this very slow process was hastened by introducing a stirrer which was moved by a large electromagnet surrounding the Dewar vessel. We extended our observations above $0^{\circ} \mathrm{C}$. up to the critical point for the sake of comparison with former results for ethane *. The agreement was satisfactory, especially if the small error of our earlier air-gauge be taken into account. Nevertheless we cannot consider the vapourpressures as accurate within one per cent.

It had struck us that ethane, whose pressures at ordinary temperatures are much lower than those of carbon dioxide, has higher pressures at very low temperatures. It appears, however, from our results that this is entirely due to the solidification of carbon dioxide, the liquid curve for this substance, as far as we could follow it, remaining above the ethane curve. The two liquid curves do not intersect, and so far there is no evidence of association of liquid carbon dioxide. 'The etbane curve intersects the solid carbon-dioxide curve at $-63^{\circ} \mathrm{C}$.

University College, Dundee.

XVI. A Voltameter for Small Currents. By R. A. LeHFELDT†.

T $N$ the course of some experiments with mercury voltameters I had a conversaticn with Mr. E. (. C. Baly, during which the suggestion of a remarkably simple form of instrument arose. This $I$ bave realized in practice, as follows:-

A glass tube of from 0.5 to $1.5 \mathrm{~mm}$. bore is provided with a pair of platinum electrodes, sealed in near the ends; the ends are then drawn out to a small diameter. The tube so prepared is filled-by means of the water-pump-with mercury throughout, except for one drop of mercurous-nitrate solution in the middle of its length; the ends of the tube are then sealed off. The tube is placed vertically, and the upper portion of mercury made the anode, the lower the cathode. The drop of solution creeps up the tube at a rate proportional to the current flowing, the movement being

* Phil. Mag. [5] xliv.p. 174.

+ Communicated by the Physical Society : read Nov. 8, 1901. 
measured by any convenient scale, preferably one etched on the glass, with or without a micrometer.

For the successful construction of the apparatus the following points should be attended to :-The parts of the tube where the electrodes are sealed-in should should not be widened, else difficulty in filling is likely to ensue. The filling can be done by placing the tube-aslant-with one point dipping under mercury, in a dish. The mercury is covered by solution: when enough has been drawn in by the pump to form one electrode, the point is lifted momentarily so as to allow solution to flow in instead; then depressed, when more mercury enters, to form the other electrode. The filling is regulated most conveniently by a tap sealed on to the upper end of the tube, which is subsequently detached. The solution is made hy weighing out about $26 \cdot 3$ milligrams of mercurous nitrate per c.c. of water (i.e. decinormal), and adding enough nitric acid to dissolve the basic salt that forms. The currentdensity may be anything up to 10 or 15 milliamperes per sq. $\mathrm{cm}$.; more than that causes polarization. Hence a tube of 2 sq. $\mathrm{mm}$. cross-section (ordinary Sprengel-pump tuling) will take $0 \cdot 3$ milliampere.

The electrochemical equivalent of mercurous mercury is $7 \cdot 470$ grams per ampere per hour, or 0.5509 c.c. Hence with a current-density of 0.010 ampere/sq. cm., the rate of movement would be $0.005509 \mathrm{~cm}$. per hour, or about $1 \mathrm{~mm}$. a day. The meter is therefore eminently adapted to measure long-continued currents of very small magnitude. Moreover, with proper precantions it may be shunted, as, apart from temperature changes, the resistance keeps steady.

The following is a record of such an instrument :-

Cross-section of tube $0.624 \mathrm{~mm}$.: length of thrend of solution about $6 \mathrm{~mm}$. Micrometer used, 1 scaledivision $=0.0785 \mathrm{~mm}$.

Time. Micrometer.

$\mathrm{h}$ m $\quad 40 \cdot 0$

Oct. 18. $11 \quad 10 \quad 40^{\circ} 0 \quad$ Started current of $1 / 12000 \mathrm{amp}$.

$1215 \quad 41 \cdot 0$

$1315 \quad 42 \cdot 0 \quad$ Stopped.

Oct. 21. Reset micrometer.
$1150 \quad 40.0 \quad$ Started current of $1 / 12000 \mathrm{amp}$.
$15 \quad 40 \quad 43 \cdot 7$

Oct. $22 . \quad 950 \quad 60 \cdot 5$

Calculated rate of movement 1 micrometer-division in 1.067 hours; observed rate $1 \cdot 073$. The small discrepancy is no doubt due to errors of experiment, and could be diminished by greater care in calibration, measurement ot current, and of distance moved. 